\title{
Implementasi Pendidikan Agama dalam Membangun Kerukunan Umat Selama Pandemi Covid-19 pada Anak Usia Dini di Kecamatan Binjai Utara
}

\author{
Safria Andy ${ }^{1 *}$, Fakhraini Zahra Afifa ${ }^{2}$, Nuh Aulya Sari Lubis ${ }^{3}$, Regina Melina \\ Ramadhani ${ }^{4}$, Suci Permata Sari ${ }^{5}$ \\ ${ }^{1}$ Universitas Islam Negeri Sumatera Utara Medan, Indonesia \\ ${ }^{2}$ Universitas Islam Negeri Sumatera Utara Medan, Indonesia \\ ${ }^{3}$ Universitas Islam Negeri Sumatera Utara Medan, Indonesia \\ ${ }^{4}$ Universitas Islam Negeri Sumatera Utara Medan, Indonesia \\ ${ }^{5}$ Universitas Islam Negeri Sumatera Utara Medan, Indonesia \\ * Corresponding Author. E-mail: ${ }^{1}$ safriaandy@uinsu.ac.id
}

\begin{abstract}
Abstrak
Saat ini pandemi Covid-19 masih sebagai pandemi berkepanjangan, Dengan adanya penyebaran virus ini, pemerintah harus membuat semua kegiatan masyarakat mengalami penyesuaian, mulai dari mengalihkan kegiatan menjadi di rumah saja sampai diterapkannya kebijakan physical distancing serta protokol kesehatan lainnya jika masyarakat akan melakukan kegiatan di luar rumah.Kegiatan KKN-DR (Kuliah Kerja Nyata - Dari Rumah) bertujuan untuk memberikan pengalaman kerja nyata di lapangan dalam bidang membentuk sikap mandiri dan tanggung jawab dengan mengedepankan protokoler kesehatan sesuai dengan intruksi pemerintah. Namun yang menjadi praktek utama dalam pelaksanaan KKN ini adalah di rumah saja, atau yang dikenal dengan KKN DR. Moderasi beragama dapat kita pahami dengan perilaku beragama yang seimbang antara keyakinan agama sendiri dan menghargai agama orang lain yang berbeda keyakinan, sehingga tidak ada tindakan ekstrem dan berlebih lebihan dalam peraktek keagamaan dan lingkungan dalam hidup yang damai. Observasi Dilakukan untuk mendapatkan data dan informasi yang diperlukan dan kemudian disatuakan melalui pengamatan langsung pada tempat penelitian tentang bagaimana implementasi moderasi beragama dimasa pandemi di Kelurahan Kebun Lada Kecamatan Binjai Utara.
\end{abstract}

Kata Kunci: Anak Usia Dini (AUD), Kerukunan Umat, Pendidikan Agama.

\section{Implementation of Religious Education in Building Community Harmony During the Covid- 19 Pandemic in Early Childhood in North Binjai District}

\begin{abstract}
Currently the Covid-19 pandemic is still a prolonged pandemic. With the spread of this virus, the government must make all community activities undergo adjustments, starting from shifting activities to being at home until the implementation of physical distancing policies and other health protocols if people will carry out activities outside The KKN-DR (Real Work Course - From Home) activity aims to provide real work experience in the field in the field of
\end{abstract}


forming an independent and responsible attitude by prioritizing health protocols in accordance with government instructions. However, the main practice in implementing this KKN is at home, or what is known as KKN DR. We can understand religious moderation with a balanced religious behavior between one's own religious beliefs and respect for the religions of others who have different beliefs, so that there are no extreme and excessive actions in religious practice and a peaceful environment in life. Observations were carried out to obtain the necessary data and information and then put them together through direct observation at the research site on how to implement religious moderation during the pandemic in Kebun Lada Village, North Binjai District.

Keywords: Early Childhood (AUD), Community Harmony, Religious Education.

\section{Pendahuluan}

Saat ini pandemi Covid-19 masih sebagai pandemi berkepanjangan. Pada mulanya Covid-19 ini merupakan kasus penyakit jenis baru yang belum pernah teridentifikasi sebelumnya pada manusia di Wuhan, Provinsi Hubei, China pada akhir 2019.Virus ini menyerang sistem pernapasan pada manusia, menginfeksi paru-paru hingga dapat menyebabkan kematian.Penyebaran virus ini dapat tertular melalui droplet (percikan air liur) dengan kecepatan penularan yang tinggi, kemudian mulai menyebar ke seluruh dunia.Sehingga pada maret 2020, World Health Organization (WHO) menetapkan Coronavirus Disease 19 (Covid 19) ini menjadi wabah global dan terus berlanjut hingga sekarang. Di Indonesia sendiri menurut data yang dikeluarkan oleh Gugus Tugas Percepatan Penanganan Covid-19 Republik Indonesia, jumlah kasus yang dinyatakan Positif sampai 6 Agustus 2021 adalah sebanyak 3.568 .331 orang dengan jumlah kematian 102.375 orang.

Dengan adanya penyebaran virus ini membuat semua kegiatan masyarakat harus mengalami penyesuaian, mulai dari mengalihkan kegiatan menjadi di rumah saja sampai diterapkannya kebijakan physical distancing serta protokol kesehatan lainnya jika akan melakukan kegiatan di luar rumah. Pembatasan kegiatan masyarakat ini bertujuan mencegah dan menekan laju penularan.Salah satu dampak pembatasan kegiatan masyarakat ini adalah terdampaknya kegiatan beribadah
masyarakat.Indonesia sebagai negara yang berdasarkan Ketuhanan yang Maha Esa dimana kegiatan-kegiatan beribadah seperti doa-doa massal itu termasuk aktivitas sehari-hari bagi seluruh warga Indonesia.Dengan adanya Covid-19 ini kegiatan-kegiatan masyarakat dalam beribadah ini tidak dapat dilaksanakan secara langsung dan harus dibatasi.

Kementerian Agama mengambil peran penting untuk menghadapi pandemi Covid-19 dengan berbagai keputusankeputusan yang bertujuan dengan berdasarkan moderasi beragama. Salah satu contohnya adalah Edaran Menteri Agama Nomor: SE 1 tahun 2020 berisi tentang Melakukan Protokol dalam penanganan Covid-19 di tempat-tempat ibadah. Dengan adanya edaran ini yang berisi memutuskan rantai virus Covid-19 di tempat-tempat ibadah dengan cara mensosialisasikan kepada masyarakat agar tetap melakukan kegiatan-kegiatan ibadah di rumah. Dalam hal ini Kementerian Agama mengajarkan masyarakat agar lebih mementingkan sikap atau perilaku moderasi dalam melaksanakan ajaran-ajaran agama masingmasing.

Moderasi beragama dapat kita pahami dengan perilaku beragama yang seimbang antara keyakinan agama sendiri dan menghargai agama orang lain yang berbeda keyakinan. Dengan memperlakukan orang lain dengan sopan, santun dan hormat dengan dapat menerima maupun menghargai satu sama lain walaupun memiliki perbedaan dalam beragama. Moderasi beragama merupakan cara pandang, sikap dan perilaku kita dalam 
memposisikan diri dalam beragama tanpa berlebih-lebihan atau tidak ekstrem. Dalam hal ini dapat kita garis bawahi tidak berlebihan yang diartikan cara menempatkan dalam satu pemahaman yang teliti dengan memperhatikan pada konteks agama, konstitusi Negara, kearifan lokal, dan toleransi bersama.

Selain kegiatan ibadah, Covid-19 juga menyebabkan kegiatan pendidikan terganggu tak terkecuali kegiatan pendidikan perguruan tinggi.Kegiatan Kuliah Kerja Nyata yang merupakan Salah satukegiatanmengajar mahasiswa di luar kelas juga terpengaruh. KKN dapat diartikan sebagai bagian dari proses pembelajaran dan pengembangan masyarakat yang meliputi: (1) salah satu kegiatanbelajar siswa, (2) dilaksanakan di lapangan, (3) beberapa bentuk pengabdian kepada masyarakat, dan (4) bermanfaat.dalam membantu masyarakat mengatasi tantangan pembangunan.

Kota Binjai adalah salah satu daerah yang berstatus kotamadya di wilayah Provinsi Sumatera Utara. Secara astronomis Kota Binjai terletak diantara $3^{\circ} 31^{\prime} 40^{\prime \prime}$ $3^{\circ} 40^{\prime} 2^{\prime \prime}$ Lintang utara dan 98 $27^{\prime} 3^{\prime \prime}$ 98०32'32" Bujur timur dengan tinggi permukaan laut adalah $28 \mathrm{mdpl}$. Kota Binjai memiliki luas daerah seluas 90,23 $\mathrm{km}^{2}$, terdiri dari 5 kecamatan yaitu Kecamatan Binjai Selatan, Kecamatan Binjai Kota, Kecamatan Binjai Timur, Kecamatan Binjai Utara, Kecamatan Binjai Barat. Kota binjai merupakan salah satu daerah yang termasuk dalam wilayah Strategis Nasional Perkotaan MEBIDANGRO (Kota Medan, Kota Binjai, Kab Deli Serdang dan Karo).

Jumlah penduduk Kota Binjai menurut data Badan Pusat Statistik Kota Binjai pada tahun 2017 adalah sebanyak 270.926jiwa. Dengan penduduk terbanyak terdapat di Kecamatan Binjai Utara sebanyak 77.931 atau sekitar 28,76\% dari total penduduk. Di Kecamatan Binjai Utara ini jumlah penduduk berdasarkan agama terdiri dari agama Islam sebanyak $89.33 \%$, Protestan sebanyak $7.21 \%$, Katolik 1.03\%,
Hindu $0.07 \%$, Budha $2.36 \%$ dan lainnya sebanyak $0.01 \%$. Dengan demikian dapat dilihat agama yang dianut masyarakat Kecamatan Binjai Utara cukup beragam.

Kecamatan Binjai Utara memiliki luas daerah seluas $23,59 \mathrm{~km}^{2}$ dan memiliki sembilan kelurahan yaitu: Kelurahan cengkeh turi, Kelurahan dama, Kelurahan jati karya, Kelurahan jati utomo, Kelurahan jati Negara, Kelurahan kebun lada, Kelurahan nangka, Kelurahan pahlawan, dan Kelurahan tamda hulu. Kecamatan Binjai Utara memiliki wilayah pariwisata yaitu taman PGRI, Peternak kelinci, vihara uan tee bio, kuliner masakan daging kelinci, dan di jalan perintis kemerdekaan yang merupakan pusat kebun dan pasar lada, adapun pada Kecamatan Binjai Utara mata pencaharian masyarakatnya lebih dominan sebagai pedagang.

Kajian mengenai moderasi beragama menarik untuk dibahas. Permasalahan ini menjadi daya tarik untuk penelitian walaupun dimasa pandemi penelitian ini mengenai implementasi moderasi beragama yang ada di Keluruhan Kebun Lada, Kecamatan Binjai Utara.

\section{Metode}

Pendekatan kualitatif dengan metode deskriptif adalah metode atau pendekatan yang digunakan pada penelitian ini.Penelitian kualitatif adalah pengumpulan data pada suatu alamiah dengan maksud menafsirkan fenomena yang ada dimana penelitian adalah kata kunci, pengambil contoh sumber data yang dilakukan secara Purposive and snowball, teknik triagulasi (gabungan), data analisis indukatif/ kualitatif, dan kualitatif hasil penelitian lebih menekankan makna daripada generalisasi. Sementaraitu, metode yang dilakukan adalah metode deskriptif. Penelitian kualitatif tidak melalui statistik, kemudian melalui pengumpulan data, analisis, dan interprestasikan. Biasanya berhubungan dengan sosial dan kemanusian masalah yang bersifat interdisipliner, dengan fokus pada multimethod, 
naturalistik, dan interpretatif (dalam pengumpulan data, paradigma, dan interprestasi). Setiap beraneka ragam penelitian mempunyai ciri khas tersendiri yang menunjukkan karakteristik penelitian itu sendiri ${ }^{1}$.

Menurut Bogdan dan Taylor yang dikutip oleh Moleong, metodologi kualitatif adalah proses penelitian yang menghasilkan data deskriptif berupa kata-kata tertulis atau dari orang dan perilaku yang dapat diamati ${ }^{2}$.

Penelitian kualitatif adalah penelitian yang digunakan untuk tujuan memahami fenomena apa yang dialami subjek penelitian,misalnya perilaku persepsi, motivasi, tindakan, dan lainlain.holistik dengan menggambarkan dalam kata-kata atau bahasa, dalam konteks kasus alami menggunakan metode alami yang berbeda $^{3}$.

Kemudian, dalam penelitian ini, peneliti mencoba mencari tahuapa yang pentingmengenai moderasi beragama di masa pandemi di Kelurahan Kebun Lada Kecamatan Binjai Utara.

\section{Latar penelitian}

Peneliti melihat situasi dan kondisi penelitian yang dipilih adalah bagaimana Implementasi Moderasi dalam Beragama.Peneliti melihat fenomena yang terjadi di tengah masyarakat kelurahan kebun lada, kecamatan Binjai Utara, kota Binja ini.

Dalam latar belakang sosial kemasyarakatan, Lokasi penelitian ini terdiri dari berbagai kepercayaan dan latar belakang sosial masyarakat, dari sinilah ditemukan banyak informasi secara lisan dari hasil observasi dari subjek penelitian yang diteliti. Ketikamengidentifikasi sumber informasi penelitian, peneliti juga

${ }^{1}$ Muhammad Shaleh Assingkily, Penelitian Tindakan Kelas (Meneliti dan Membenahi Pendidikan dari Kelas), (Medan: CV.Pusdikra Mitra Jaya, 2021)

${ }^{2}$ Lexy J, Moleong, Metodologi Penelitian Kualitatif, Cet I (Bandung: Remaja Rosdakarya,2000),3

${ }^{3}$ Lexy J, Moleong, Metodologi Penelitian Kualitatif,6 mengacu pada parameter ide Mules dan Huberman sebagai kontekstual (suasana, keadaan atau konteks), perilaku, peristiwa dan proses.

Oleh karena itu, penelitian ini dilakukan dengan menggunakan pengumpulan informasi dari observasi maupun wawancara dan studi dokumentasi yang berkaitan langsung dengan Implementasi Moderasi beragama pada kelurahan kebun lada kecamatan Binjai Utara kota Binjai.

\section{Subjek Penelitian}

Subjek penelitian dari tulisan ini adalah Masyarakat Kelurahan Kebun lada, Pemenrintahan yang ada di Kelurahan kebun lada. Di mana bertujuan untuk mendapatkan informasi dari masyarakat dan petinggi yang ada di Kelurahan Kebun Lada.Oleh karena itu, dalam penelitian kualitatif ini adalah rational sampling dan randomsampling.Penelitisecara spontan mengumpulkan data menggunakan teknik observasi dengan terjun langsung ke lapangan untuk mengumpulkan data dan informasi dengan melakukan observasi dan wawancara sebagai sumber data dan Terakhir, melakukan penelitian dan menulis dokumentasi.

\section{Teknik pengumpulan data}

Teknik pengumpulan data dalam penelitian dilakukan melalui observasi, wawancara, dan dokumentasi

a. Observasi

Observasi adalah suatu metode atau metode analisis sistematis dan pencatatan perilaku dengan melihat atau mengamati secara langsung individu atau kelompok.implementasi moderasi beragaa dimasa pandemi di Kelurahan Kebun Lada Kecamatan Binjai Utara.

b. Wawancara

Wawancara adalah percakapan informasi dengan tujuan untukmemperoleh informasi dari mulut ke mulut, sebagaisumber data dan informasi dilakukan dengan tujuan untuk menggali informasi tentang subjek wawancara. Penelitian ini menggunakan wawancara 
terstruktur, pertanyaan-pertanyaan yang telah disiapkan dan prosedur tanya jawab untuk memperoleh informasi dan untukmemperoleh informasi dari pertanyaan-pertanyaan yang telah disiapkan.

Wawancara dapat berfungsi sebagai sarana utama pengumpulan data. Pedoman yang dikembangkan sangat penting ketika melakukan wawancara untuk menjaga wawancara dalam konteks masalah, tetapi tidak menutup kemungkinan bahwa pertanyaanakan mengikuti besarnyatanggapandari sumber.

c. Studi Dokumentasi

Studi dokumentasi adalah suatu cara penelitian dalam pengumpulkan data yang telah mendapatkan catatan-catatan penting terkait hal yang diselidiki untuk memperoleh data yang lengkap, valid dan tidak berdasarkan perkiraan atau dugaan.

Studi dokumentasi dalam penelitian ini untuk memperkuat analisis penelitian yang berkaitan dengan implementasi moderasi beragama di masa pandemi covid19 di Kelurahan Kebun Lada, Kecamatan Binjai Utara.

\section{Hasil dan Pembahasan}

Dari hasil wawancara dan observasi yang dilakukan peneliti, maka penulis dapat menggambarkan mengenai Implementasi Pendidikan Agama Dalam Membangun Kerukunan Umat Selama Pandemi Covid 19 Pada Anak Usia Dini Di Kecamatan Binjai Utara. Dimana masyarakat dengan pemeluk agama yang cukup beragam. Dari 77.931 jumlah penduduk Binjai Utara berdasarkan agama menurut dari data BPS 2017 terdiri dari agama Islam sebanyak $89.33 \%$, Protestan sebanyak 7.21\%, Katolik $1.03 \%$, Hindu $0.07 \%$, Budha $2.36 \%$ dan lainnya sebanyak $0.01 \%$.

Dengan keberagaman agama, ras, dan budaya masyarakat Binjai Utara Khususnya DiKelurahan Kebun Lada melaksanakan moderasi beragama dengan baik.Karena Keberagaman atau Pluralisme adalah keniscayaan karena sudah menjadi kehendak Tuhan agar manusia saling menyapa, saling mengenal, berkomunikasi dan bersatu.

Masyarakat Binjai utara dapat dipandang sebagai komunitas religius; sikap masyarakat yang toleran tanpa diskriminasi, termasuk agama; lembaga yang ada (pendidikan, keagamaan, sosial) telah lama berfungsi mendidik dan mendorong masyarakat; komitmen masyarakat terhadap konstruksi Pancasila, yaitu nilai dan norma agama yang ada; Perantokoh agama, tokoh masyarakat dan pemuda cukup penting. Namun upaya untuk terusmemajukan kerukunan umat beragama itu penting, karena "harga kerukunan umat beragama sangat tinggi". Jika orang-orang terpecah maka akan sulit untuk menyatukan mereka dan dapat menyebabkan perpecahan dan kebrutalan. Kebrutalan yang tidak terkendali akan menghancurkan dan merusak tatanan yang ada.

Karena Moderasi merupakan hal yang diajarkan oleh setiap agama, bukan hanya diajarkan oleh Islam yang merupakan wujud tersendiri dari pendidikan agama Islam.Pendidikan agama sejak usia diri dapat membangun lingkungan masyarakat yang saling menghargai satu sama lain, sebab pada usia dini pun anak-anak sudah dibekali akhlak yang baik dalam menyikapi perbedaan agama yang ada dalam lingkungannya. Moderasi adalah suatu kebajikan yang mendorong terciptanya keselarasan dan keseimbangan sosial dalam kehidupan pribadi, keluarga dan masyarakat dengan hubungan antar manusia yang lebih luas.Moderasi beragama adalahkandungan nilai dan amalan yang paling tepat untuk tercapainya kemaslahatan bersama. Moderasi, keadilan, dan sikap mental yang seimbang sangat penting untuk mengelola keragaman kita.

Berdasarkan observasi dan wawancar masyarakat Kelurahan Kebun Lada, Kecamatan Binjai Utara, Dalam masa pandemi ini tidak hilangnya moderasi beragama di mana masyarakat sekitar saling mengahargai, menghormati, bersilaturahmi 
dan bertoleransi tinggi.Di kelurahan Kebun Lada Kecamatan Binjai Utara juga terdapat banyak anak-anak yang kesehariannya bermain bersama, mereka bermain tanpa memandang teman mereka yang berbeda agama, suku, dan rasnya.

Di Kelurahan Kebun Lada ini mayaoritas menganut agama Islam, di masa pandemi masyarakat beragama Islam tetap menjalankan shalat di mesjid dengan mematahui protokol kesehatan. Salah satu staff di kecamatan mengatakan "masyarakat Kelurahan Kebun Lada kerukunan umat beragama masih kuat dan toleransinyakuat, saling menghargai antar pemeluk agama."

Adapun kondisi keberagaman moderasi agama di Kelurahan Kebun Lada Kecamatan Binjai Utara terjalin dengan sangat baik dan harmonis, dimana masingmasing masyarakat saling menghargai antar agama satu sama lain.

Dari hasil wawancara yang dilakukan maka salah satu warga Kelurahan Kebun Lada, Ibu Halimah mengatakan "pada saat hari raya Idul Fitri masyarakat mengadakan open house dan yang datang tidak hanya warga muslim saya akan tetapi warga yang non-Muslim ikut bersilaturahmi"

Di masa kondisi pandemi saat ini tentu merubah aktivitas masyarakat, masyarakat yang biasanya melakukan aktivitas di luar rumah seperti berjualan di pasar, bergotong-royong, dan melakukan perwiritan akhirnya tertunda sampai keadaan normal kembali seperti sebelum pandemi covid-19.

Masyarakat tidak luput untuk serta dalam moderasi yang sudah menjadi kebiasaan yang dilakukan masyarakat sekitar, baik yang beragama islam maupun yang non islam. Walaupun di masa pandemi ini dengan melakukan kebiasaan yang tidak normal seperti sebelum pandemi.Dengan menggunakan masker dan mencuci tangan.

Dengan itu, maka masyarakat Kelurahan Kebun Lada, Kecamatan Binjai Utara masih menjaga yang namanya moderasi beragama karena dengan menerapkan moderasi beragama yang baik akan timbulnya tali persaudaraan yang kuat, kerukunan, dan kedamaian walaupun dimasa pandemi ini. Karena moderasi beragama ini adalah kunci terjalinnya kedamaian, kerukunan, dan menghargai sesama. Kerukunan dan moderasi beragama ini merupakan bentuk dari pendidikan anak usia dini yang dilakukan para orang tua (keluarga) serta lingkungan yang mendukung untuk pertumbuhan anak dalam mewujudkan moderasi beragama (kerukunan umat) di Kelurahan Kebun Lada Kecamatan Binjai Utara Kota Binjai.

\section{Analisa Dr. Safria Andy, MA}

Pendidikan merupakan suatu upaya dalam membentuk siswa, mahasiwa dan masyarakat kepada perilaku yang bermoral baik atau di dalam bahasa islaminya adalah membentuk manusia yang berakhlak mulia dan kajian tersebut dikenal dengan pendidikan Islam. Upaya di atas merupakan upaya utama yang diciptakan untuk membangun kedamaian di dalam berinteraksi antar satu siswa, mahasiswa dan masyarakat satu dengan lainnya. Intraksi yang berbuahkan kedamaian dari yang telah dibangun oleh kalangan siswa, mahasiswa dan masyarakat sekitar akan memicu kepada kemajuan dalam berkehidupan sosial yang sejahtera.

Agama-agama, menjadikan sebuah kajian perilaku adalah bagian utama yang dikaji di dalam ajaran keagamaannya. Islam, sangat mengedepankan kajian perilaku di dalam ajaran keislaman yang berawal dikupas pada kajian ketauhidan, yaitu kajian yang mengajarkan kepada umatnya bahwa semua makhluk yang ada id langit dan bumi beserta langit dan buminya adalah ciptaan Allah Swt., dan akan kembali kepada Allah Swt. Kajian tersebut menjadikan kajian yang menyadarkan manusia dan jin untuk tidak sesuka hatinya di dalam berbuat yang mengakibatka munculnya ketidak damaian di dalam berkehidupan. Dengan kajian ketauhidan, akan memberikan wawasan 
yang luas bagi hamba Allah Swt Tuhan yang Mahaesa di dalam mengelola dunia dan berkehidupan yang penuh dengan kedamaian. Islam memiliki prinsip beragama dengan bertujuan membangun kedamaian di alam semesta (jagad raya) yang kita cintai bersama. Alat utama dalam menciptakan kedamaian di alam semesta tersebut adalah dengan menciptakan manusia yang berhambakan diri kepda Allah Swt., Tuhan yang Mahaesa dan berakhlak mulia. Akhlak mulia merupakan alat untuk membangun kedamaian alam semesta tersebut. Akhalk mulia akan muncul dengan pengakuan seorang hamba bahwa bumi dan alngit beserta isinya merupaan ciptaan Allah Swt Tuhan yang Mahaesa dan mengembalikan segala nya kepada-Nya sehinga tidak terjadi keserakahan di antara manusia di dalam mengelola dunia dan tidak terjadi kesombongan jua yang akhirnya wujud tersebut akan membangun kasih-sayang antar makhluk sebab, siapapun dan apapun dia adalah ciptaan Allah Swt Tuhan yang Mahaesa yang mesti untuk dilindungi dan dibimbing kepda jalan yang mampu bersama dalam menciptakan kedamian.

Kerukunan, merupakan tujuan kedua setelah membangun manusia hamba Allah Tuhan yang Mahaesa yang berakhlak mulia. Islam tidak akan pernah lepas dari kajian dua hal tersebut, menciptakan manusia hamba Allah ( Tuhan yang Mahaesa) yang berakhlak mulia dan menciptakan kerukunan antar makhluk ciptaan Allah Swt. Pendidikan keislaman akan terlihat sukses, mana kala telah terwujud siswa, mahasiswa dan masyarakat yang memiliki kemuliaan akhlak dan menerapkannya di dalam kehidupan yang rukun yang tidak memandang perbedaan baik sosial, ekonomi maupun akidah. Wujud tersebut terlaksanakan karena pemahaman kajian bahwa langit dan bumi beserta isinya adalah ciptaan Allah Swt., (Tuhan yang Mahaesa) dan merupakan tanggungjawab utama di dalam mengelolanya di jalan Allah Swt untuk memperoleh rasa rido dan cinta-Nya serta tersugesti dan termotivasi yang tinggi di dalam mewujudkan kedamaian di dalam berkehidupan sosial di alam semesta ini.

Kerukunan dalam beragama, merupakan suatu upaya di dalam menciptan umat umat beragama baik yang seakidah terutama yang berbeda akidah agar solid di dalam menciptakan kerukunan, sehingga akan terwujud kedamaian di dalam berkehidupan bertetangga dan berjiran yang senantiasa saling melakukan tolong menolong antar sesama jiran bertetangga. Tolong menolong yang dilakukan tdak memperhatikan perbedaan aliran paham keislaman (NU dan Muhammaddiyah), akidah dan bahkan juga perbedaan ekonomi (antara si kaya dan si miskin) yang bisa saja terlupakan dalam kupasan kita secara umum di negeri ini atau di seluruh penjuru dunia. Dalam Islam, akhlakulkarimah atau bahasa umumnya adalah akhlak mulia dibangun paling utama untuk terciptanya keterikatan hamba dengan Tuhannya yaitu Allah Swt., sehingga ia sadar bahwa di dalam membuktikan cintanya kepda Allah Swt., adalah dengan mengelola dunia yang telah diciptakan Allah Swt (Tuhan yang Mahaesa) agar terawat dengan baik dan otomatis terlndungi. Perawatan dan perlndungan tersebut dilakukan seorang hamba Allah Swt adalah karena-Nya sehingga tidak memperhatikan perbedan antar dirinya dengan yang lainnya, apakah beda dalam paham keislaman, beda dalaqm akidah aplagi beda di dalam dunia ekonomi dan sosial, yaitu kelas ekonomi an status sosialnya (orang rendahan apakah orang berderajat tinggi alias pejabat). Kesimpulannya Islam dapat dijadikan imam atau pemimpin di barisan terdepan di dalam merangkul teman teman yang beragama lain di dalam membangun kerukunan untuk terciptanya kedamaian di dalam berkehidupan.

Hal di atas merupan suatu kajian yang diterapkan secara perlahan lahan dan pasti di kota Binjai terutama di lingkungan Kelurahan Kebunlada tepatnya di sekitar lingkungan kantor Camat Binjai Utara. Sedari dahulu Kota Binjai, Kecamatan 
Jurnal Edumaspul, 5 (1), Year 2021 - 744

(Safria Andy, Fakhraini Zahra Afifa, Nuh Aulya Sari Lubis, Regina Melina Ramadhani, Suci Permata Sari)

Binjai Utara dan khususnya Kelurahan Kebunlada merupakan daerah yang senantiasa menjaga kedamaian di dalam berkehidupan sosial tanpa membedakan status ekonomi, sosial, aliran keislaman dan juga akidah satu dengan lainnya. Dengan mayoritas masyarakat kota Binjai dan Kecamatan Binjai Utara adalah Muslim telah mencptakan kerukunan dan kedamaian di dalam berkehidupan sosial, sehingga yang berbeda atau minoritas tetap tentram berdampingna di dalamnya.

Terlhatlah bahwa Islam sangat kental dengan kerukunan dan tidak dapat dipungikir bila Islam jua memiliki harapan yang besar untuk membangun kedamaian di muaka bumi ini. Wa Allahu A lam.

\section{Simpulan}

Berdasarkan penelitian yang sudah dilaksanakan menggunakan metode kualitatif dengan deskriptif dapat diambil kesimpulan bahwa dimasa pandemi ini tidak surutnya moderasi beragama di Kelurahan Kebun Lada, Kecamatan Binjai Utara.Di mana moderasi beragamanya masih kuat seperti toleransinya, saling menghormati dan saling menghargai.

Dengan keberagaman agama, ras, dan budaya masyarakat Binjai Utara Khususnya di Kelurahan Kebun Lada melaksanakan moderasi beragama dengan baik. Karena keberagaman atau kemajemukan adalah keniscayaan karena merupakan kehendak Tuhan, agar manusia saling menyapa, mengenal, berkomunikasi, dan bersolidaritas.

\section{Daftar Pustaka}

[1] Aidah, Siti Nur. (2020). Kitab Sejarah Covid-19. Yogyakarta: Penerbit KBM Indonesia.

[2] Assingkily, Muhammad Shaleh. (2021). Penelitian Tindakan Kelas (Meneliti dan Membenahi Pendidikan dari Kelas). Medan: CV. Pusdikra Mitra Jaya.

[3] Darlis. (2017). Mengusung Moderasi Islam di Tengah Masyarakat Multikultural. Jurnal Rausyan Fikr, 13(2).

[4] Mansur. (2007). Pendidikan Anak Usia Dini. Yogyakarta: Pustaka Pelajar.

[5] Moleong, Lexy J. (2000). Metodologi Penelitian Kualitatif. Bandung: Remaja Rosdakarya.

[6] Nahla, Shihab. (2020). Covid-19: Kupasan Ringkas yang Perlu Anda Ketahui. Ciputat: Literati.

[7] Safry, Andi. (2021). Manajemen Hati dalam Perspektif Tasawuf Akhlaqi Ibn Qoyyim Al-Jauziyyah. Yogyakarta: Kaizen Sarana Edukasi.

[8] Suwito. (2004). Filsafat Pendidikan Akhlak Ibn Miskawaih. Yogyakarta: Belukar.

[9] Tim Balitbang Kemenag RI. (2019). Moderasi Beragama. Jakarta: Badan Litbang dan Diklat Kementerian Agama RI.

[10] Ulwan, Abdullah Nashih. Pedoman pendidikan Anak dalam Islam. Terj. Saefullah Kamalie \& Hery Noer Ali, Jilid II. Semarang: Asy-Syifa.. 